\title{
Chapter 7: Raising Awareness among Australian Life Scientists
}

\author{
CHRISTIAN ENEMARK
}

\section{Introduction}

In early 2001, the year of the anthrax envelope attacks in the US, research conducted by a group of Australian scientists highlighted the security implications of the dual-use dilemma in the life sciences. This group was attempting to produce an infectious contraceptive for mice, which periodically breed out of control in parts of Australia. The scientists first spliced the zona pellucida glycoprotein 3 (ZP3) gene into a mild mousepox virus in the hope of inducing antibodies with a contraceptive effect. ${ }^{1}$ They subsequently inserted the interleukin-4 (IL-4) gene, which helps regulate immune system reactions, to boost this genetically engineered sterility treatment. However, the IL-4 gene increased the virulence of the virus such that it rapidly killed normally resistant mice. The researchers subsequently showed that the expression of IL-4 resulted in a strain of mousepox so powerful that it killed even vaccinated mice. ${ }^{2}$ A disturbing implication of this finding is that adding an IL-4 gene might similarly increase the fatality rate of smallpox (or some other poxvirus that infects humans) and potentially allow the virus to circumvent vaccination. The Australian group's findings were published in the peer-reviewed Journal of Virology, but they also attracted attention in the popular magazine New Scientist as well as in the mainstream media. ${ }^{3}$ Ethical questions posed to this experience included: Should this research have been done? Should the results have been published? How

\footnotetext{
1 Jackson, R. J., Maguire, D. J., Hinds, L. A. and Ramshaw, I. A. 1998, 'Infertility in mice induced by a recombinant ectromelia virus expressing mouse zona pellucida glycoprotein 3', Biology of Reproduction, vol. 58(1), pp. 152-9.

2 Jackson, R. J., Ramsay, A. J., Christensen, C. D., Beaton, S., Hall, D. F. and Ramshaw, I. A. 2001, ‘Expression of mouse interleukin-4 by a recombinant ectromelia virus suppresses cytolytic lymphocyte responses and overcomes genetic resistance to mousepox', Journal of Virology, vol. 75(3), pp. 1205-10.

3 Nowak, R. 2001, 'Killer virus', New Scientist, 10 January, available: http://www.newscientist.com/article/ dn311 [viewed 23 February 2010]; Broad, W. J. 2001, 'Australians Create a Deadly Mouse Virus', New York Times, 23 January, available: http://www.nytimes.com/2001/01/23/health/23MOUS.html?pagewanted=all [viewed 23 February 2010].
} 
should scientists and governments respond to dual-use dilemmas? This chapter explores recent efforts by four Australian academics, one of whom was involved in the mousepox IL-4 research, to facilitate discussion among life scientists of these and related questions.

In 2009, the US-based Alfred P. Sloan Foundation funded a pilot series of four interactive seminars for Australian scientists and students on the potential security risks of laboratory research on pathogenic micro-organisms. The seminars were designed and facilitated by a team of academics from the National Centre for Biosecurity (NCB), a collaboration of the University of Sydney and the Australian National University (ANU). This project was part of a multinational programme of education and awareness-raising on the dual-use dilemma in the life sciences, coordinated by Brian Rappert of the University of Exeter (UK). The Australian team was multidisciplinary and consisted of virologists Belinda Herring (Sydney) and Ian Ramshaw (ANU), bioethicist Michael Selgelid (ANU), and political scientist Christian Enemark (Sydney). We had sought funding to conduct these seminars because we perceived that the issue of the dual-use dilemma in the life sciences had received scarce attention in Australia at the level of higher education and professional training. In 2005 the Australian government had acknowledged, at a meeting of Biological and Toxin Weapons Convention (BTWC) member-states in Geneva, that 'Amongst the Australian scientific community, there is a low level of awareness of the risk of misuse of the biological sciences to assist in the development of biological or chemical weapons' ${ }^{4}$ Over the course of 2009, we gained the impression that little had changed since that observation was made.

At the level of government policy, Australia had recently introduced a scheme under the National Health Security Act 2007 to regulate the handling, storage, transfer and disposal of 'Security-Sensitive Biological Agents' (SSBAs). A government-run 'road show' of workshops in major Australian cities in 200809 sought to inform 'affected stakeholders' about the SSBAs scheme. As part of this, the 'dual-use dilemma' was mentioned briefly at the start of each workshop. ${ }^{5}$ After attending one of these, our impression was of a top-down, rulers-to-the-ruled, regulations-oriented approach to awareness-raising. We felt the time was ripe for some bottom-up, non-official, ethics-oriented engagement with Australian life scientists and students on the challenge of preventing the

4 Meeting of the States Parties to the Convention on the Prohibition of the Development, Production and Stockpiling of Bacteriological (Biological) and Toxin Weapons and on their Destruction, Meeting of Experts, Raising awareness: Approaches and opportunities for outreach (working paper prepared by Australia), BWC/ MSP/2005/MX/WP.29, Geneva, 21 June 2005: 1.

5 Department of Health and Ageing 2010, 2009 SSBA regulatory scheme road show, available: <http://www. health.gov.au/ssba\#roadshow > [viewed 20 January 2010]. 
destructive use of science. Our hypothesis was that an interactive seminar on the dual-use dilemma, facilitated by academics, would make for a more relaxed and fruitful forum for raising questions and discussing concerns.

\section{Preparation}

Our team of facilitators prepared for the 2009 seminar series by undertaking two days of training in December 2008. Rappert and his US colleague Nancy Connell (University of Medicine and Dentistry of New Jersey) visited the University of Sydney and we spent the first day airing our views on the dual-use dilemma and exploring issues of seminar content and awareness-raising methodology. The following day, the team and its trainers jointly conducted a two-hour demonstration seminar on campus involving around 20 participants from a variety of academic and government backgrounds. This was an opportunity for us not only to get a feel for an interactive seminar on the dual-use dilemma but also obtain feedback from participants and each other on matters of substance and style. Four weeks prior, we had distributed an invitation flyer via email to relevant university mailing lists. The flyer was reused for all four seminars in 2009 and was worded as follows:

International concern about biological weapons has increased significantly, particularly since the anthrax attacks of 2001 in the United States. Biotechnology research has great potential to benefit health and agriculture, but questions arise as to whether it might aid the deliberate spread of disease. Traditional concerns about laboratory biosafety are being increasingly complemented by growing attention to biosecurity practices within and outside of laboratories. In Australia, this is reflected in the 'security-sensitive biological agents' (SSBAs) scheme to be introduced in 2009. Beyond legal regulations, ethical questions remain including what novel threats might stem from life science research, whether and how scientists should contribute to national defence, and whether some lines of investigation are too contentious to pursue.

This interactive seminar has three aims:

1. Inform participants about current international discussions surrounding 'dual use' and 'biosecurity'.

2. Generate debate about the merits and pitfalls of proposed policy responses.

3. Provide examples of educational programmes and oversight measures related to dual-use research. 
Topics for discussion will include the funding of research, communication of research results, oversight of experiments, the responsibilities of scientists and other biosecurity stakeholders, and examples of various national and international measures being implemented or considered.

The flyer appeared on NCB letterhead featuring the University of Sydney and ANU logos and the NCB website URL (www.biosecurity.edu.au), and it acknowledged funding from the Alfred P. Sloan Foundation. We wanted to make clear to prospective participants that the seminar was academic in nature and not associated with government in any way. Our intention in so doing was to distinguish the seminar from the SSBAs 'road show' passing through Australian cities in 2008-09.

Participants at the December 2008 demonstration seminar were reminded at the outset that it was being conducted primarily for training purposes. After a brief introduction to the problem of biological weapons and the awarenessraising rationale for the following year's seminar series, Rappert spent one hour taking participants through a seminar similar to those that he and his British colleague Malcolm Dando (University of Bradford) had been conducting with scientists worldwide since 2004. ${ }^{6}$ Rappert's content, structure and style were the model for the seminars we conducted in 2009. Connell and the Australian team of facilitators then spent around 50 minutes asking participants to expand on points they had raised earlier. We concluded the demonstration seminar by eliciting feedback, thanking our guest facilitators and the participants and then inviting everyone to join us for lunch. Immediately afterwards, Rappert and Connell debriefed us on possible reasons for the success or otherwise of different aspects of the seminar. Taking these lessons on board, and building on our collective research and teaching experience as academics, we were now trained and ready to conduct discussions around Australia on the dual-use dilemma in the life sciences.

\section{The Seminars}

Over the course of 2009 we undertook seminars at the John Curtin School of Medical Research at ANU (20 March), the Department of Microbiology and Immunology at the University of Melbourne (9 June), the Centre for Infectious Diseases and Microbiology at the Westmead Hospital campus of the University of Sydney (23 July), and the Queensland Institute of Medical Research in Brisbane (17 August). Each of these took place over a one-hour period and on average attracted around 50 scientists and students. Many of the participants

6 Rappert, B. 2009, Experimental secrets: International security, codes, and the future of research, New York: University Press of America. 
in the December 2008 demonstration seminar had provided feedback that even two hours was not enough time. However, in the interests of maximising participation, we decided it would be better to have our seminar included in existing programmes of weekly one-hour seminars which scientists and students are in the habit of attending. Given limited time and a desire to avoid 'death-byPowerPoint', we settled on 11 slides:

1. Title slide ('The Dual-Use Dilemma in the Life Sciences') including NCB banner, names and university affiliations of seminar facilitators and name of sponsor.

2. Three questions:

What research should or should not be done?

How should research results be communicated?

What forms of security oversight, if any, are required for life scientists?

3. What research should or should not be done?

Example: synthetic poliovirus

4. How should research results be communicated?

Example: resurrected 1918 flu virus

5. What forms of security oversight, if any, are required for life scientists?

Example: laws and codes of conduct

6. 1972 Biological and Toxin Weapons Convention

Text of Article 1

7. National Health Security Act 2007

List of security-sensitive biological agents

8. A Code of Conduct for Biosecurity (Royal Netherlands Academy for Arts and Sciences (RNAAS) 2007)

Basic principles and target groups

9. A Code of Conduct for Biosecurity (RNAAS 2007)

Research and publication policy

10. A Code of Conduct for Biosecurity (RNAAS 2007)

Accountability and oversight

11. Thanks and contact information 
The first task was for the team of seminar facilitators to introduce themselves and their academic backgrounds. Some participants in the December 2008 demonstration seminar had indicated in feedback that they would also have liked everyone else in the room to introduce themselves. The reason given was typically that this would reveal 'who people are and where they are coming from'. Nevertheless, we decided against this, partly because it would take up too much time and most seminar attendees at a given research institution would probably already know each other, but mainly because we felt that people would speak more freely and frankly (to us) under conditions of relative anonymity.

After the facilitators' introductions, we briefly explained why the seminar was being conducted. The 'dual-use dilemma' is nothing new, we assured the participants, and can arise in any and every branch of science. Simply stated, it is the notion that the fruits of scientific endeavour can be used for purposes both good and bad. But whereas the downsides of nuclear science, for example, have been comprehensively canvassed, there has hitherto been little open discussion of the dual-use dilemma and biological weapons risks among life-science professionals. This is despite the fact that the Australian Academy of Science, along with 67 other academies worldwide, has endorsed the 2005 Statement on Biosecurity by the Interacademy Panel on International Issues. The statement acknowledges that 'some science and technology can be used for destructive purposes as well as for constructive purposes', and among the principles it offers to guide individual scientists is that 'scientists should be aware of, disseminate information about and teach national and international laws and regulations, as well as policies and principles aimed at preventing the misuse of biological research'. ${ }^{7}$ We explained that this was a challenge around the world, and that our Australian series of seminars in Canberra, Melbourne, Sydney and Brisbane was roughly mirroring the work of seminar teams based in the UK, South Africa, Israel, Japan and the US. Our seminar, unlike those the participants were used to attending as part of their institution's weekly programme, was not about presenting research findings and nor was it a research exercise in itself.

After setting the scene, we briefly explained how we wanted the seminar to run. While pointing to the political reality of government concern about the problem of biological weapons, it was not our role to make judgments about if or the extent to which this concern is justified. Nor was it the purpose of the seminar, we explained, to advocate specific practices and policies. Rather, we wanted to provide Australian life scientists and students with a forum for structured discussion among themselves of the dual-use dilemmas associated with their work. In any event, we the seminar facilitators were ourselves divided

7 Interacademy Panel on International Issues 2005, Statement on biosecurity, available: <http://www. interacademies.net/Object.File/Master/5/399/Biosecurity\%20St..pdf > [viewed 9 January 2010]. 
on possible solutions to dual-use dilemmas. Our objectives of education and awareness-raising would be best achieved if the seminar participants did most of the talking over the hour. We then indicated our intention to allow roughly equal time for participants to discuss each of three questions:

- What research should or should not be done?

- How should research results be communicated?

- What forms of security oversight, if any, are required for life scientists?

These questions are along the same lines as those that Rappert and Dando have identified as central to current dual-use knowledge debates. ${ }^{8}$ A different facilitator would initiate discussion of each question with a real example of a dual-use dilemma, then it would be up to the seminar participants to talk through the issues as they saw them and in the light of any comments we made. At the first two seminars (Canberra and Melbourne), it was difficult to get someone in the room to be the first to talk about each question. On the advice of a Melbourne seminar participant who had lunch with us afterwards, we later employed the device of first asking for a show of hands. This quickly served to demonstrate to each participant that others in the room also had an opinion and, more importantly, that opinions differed.

To stimulate discussion on our first question (what research should or should not be done?), we referred to an experiment that involved synthesising the genome of a pathogen. The dilemma is:

1. Synthesis of the genomes of viruses theoretically allows the introduction of mutations or novel sequences that can be used to study the function of particular genes or regulatory sequences.

2. Synthesis technology would obviate the need to source pathogens from natural reservoirs in other parts of the world or from other laboratories. It could also facilitate recotnstruction of extinct pathogens and enable construction of novel pathogens.

Our example was a project in which US scientists sponsored by the US Department of Defense spent three years synthesising the 7500 chemical units of poliomyelitis (polio) virus. Referring to the published polio virus RNA genome, they strung together corresponding DNA sequences purchased over the Internet. This was used in a cell-free extract to create live virus that paralysed and killed mice. The results, published in 2002, showed that eradicating a virus in the wild might not mean it is gone forever. ${ }^{9}$ We asked the seminar participants: Should

8 Rappert, B. 2007, 'Education for the life sciences' in Rappert, B. and McLeish, C. (eds), A web of prevention: Biological weapons, life sciences and the future governance of research, London: Earthscan, p. 60.

9 Cello, J., Paul, A. V. and Wimmer, E. 2002, 'Chemical synthesis of poliovirus cDNA: generation of infectious virus in the absence of natural template', Science, vol. 297(5583), pp. 1016-8. 
this research have been done? In general, responses to this question tended towards preferring a permissive approach, but there was some variation from one institution to the next. In Brisbane, an initial show of hands indicated a majority were in favour of the experiment having been done, but most Sydney participants adopted a neutral position. Nobody offered the view that polio virus synthesis was particularly groundbreaking or important work. Rather, as one Brisbane participant observed, 'This was not research, it was just applying known technology'. A Melbourne participant posed the rhetorical question: 'why would you bother?' and in Sydney one person likewise suggested that the experiment was 'pointless' but otherwise 'morally neutral'.

At this point the seminar discussion would usually quickly turn, as we anticipated, to a more general consideration of scientists' freedom to experiment. A common theme was that no experiment exists (or can be judged) in isolation, but rather builds on research that has gone before; there is a general backdrop of pre-existing scientific knowledge and technological capabilities. To test this view, we would offer a proposition along the lines of 'But what if one research project was what turned a reasonably foreseeable, dangerous but theoretical possibility into a real danger?' A Canberra participant commented that 'evil applications of science cannot always be predicted' and an attitude prevalent throughout the seminar series was that shutting down lines of research might deprive humanity of important, life-saving discoveries. On this point, one of the more interesting moments during the Melbourne seminar was when one participant, an influenza researcher, pointed to work currently being carried out which involves increasing the transmissibility of a pathogen. The dilemma is:

1. For public-health planning purposes, it may be important to know whether a naturally occurring infectious-disease threat could be worsened by the evolution of a pathogen into a more transmissible form.

2. A pathogen might be more useful for biological weapons purposes if it is more easily transmitted through a target population.

The World Health Organization is presently sponsoring research to find out whether the $\mathrm{H} 5 \mathrm{Nl}$ avian influenza virus could mutate to produce a human influenza pandemic. There is hope that, by re-assorting (mixing) H5Nl with human influenza viruses in the laboratory, scientists may determine how dangerous the hybrid virus would be and the likelihood of it causing a pandemic. One such experiment in re-assortment has found that transmissibility 
is not increased. ${ }^{10}$ However, a successful experiment of this kind could result in a man-made pandemic influenza virus that would need to be kept extremely secure against theft or leakage from the laboratory.

From time to time, some participants appeared reluctant to mesh scientific and ethical concerns. One pragmatic pronouncement made at the Brisbane seminar was that 'if I don't do it, someone else will, unless you inhibit us all'. This then prompted the observation that 'any restriction not globally applied has no value'. At all the seminars, there invariably arose a question along the lines of 'Who decides at which point something is too dangerous?' In reply, one of the facilitators would ask participants their views on a hypothetical experiment involving chemical synthesis of variola (smallpox) virus, a pathogen which no longer exists in nature. There was some disagreement over the technical feasibility of producing a virus capable of infecting and sickening humans, but no one argued that there would be much scientific merit in doing so. On the question of whether such work should or should not be done, as a matter of morality, one Melbourne participant replied by asking the group: 'Hang on, is this a scientific or a social issue?' This in turn received the reply 'Others will say it is a social issue, even if we don't think so.'

Attention then turned to what might be considered the lifeblood of science information and its sharing. The second question we posed was closely related to the first: a person's opinion on whether or how to communicate research results is likely to be impacted by whether they think the research should have been done at all. To stimulate discussion, we referred to a pair of experiments that centred on genetic sequencing of a pathogenic micro-organism. The dilemma is:

1. Sequencing the genetic code of entire pathogens or specific genes of pathogens could assist in understanding the nature of the pathogen and in the development of new vaccines or treatments for the disease it causes.

2. Gene-sequence data could be used to reconstruct a pathogen (or one with its harmful characteristics) for deployment against a target population with no natural immunity.

Our example was research results, published in 2005, on the complete genetic sequencing of the 1918 influenza A $(\mathrm{HlNl})$ virus and the resurrection thereof using reverse genetic techniques. ${ }^{11}$ This revealed (and reproduced, in animals

10 Maines, T. R., Li-Mei Chen, Matsuoka, Y., Chen, H., Rowe, T., Ortin, J., Falcón, A., Nguyen, T. H., Le Quynh Mai, Sedyaningsih, E. R., Syahrial Harun, Tumpey, T. M., Donis, R. O., Cox, N. J., Subbarao, K. and Katz, J. M. 2006, 'Lack of transmission of H5N1 avian-human reassortant influenza viruses in a ferret model', Proceedings of the National Academy of Sciences, vol. 103(32), pp. 12,121-6.

11 Taubenberger, J. K., Reid, A. H., Lourens, R. M., Wang, R., Jin, G. and Fanning, T. G. 2005, 'Characterization of the 1918 influenza virus polymerase genes', Nature, vol. 437(7060), pp. 889-93; Tumpey, T. M., Basler, C. F., Aguilar, P. V., Zeng, H., Solorzano, A., Swayne, D. E., Cox, N. J., Katz, J. M., Taubenberger, J. K., Palese, P. and Garcia-Sastre, A. 2005, 'Characterization of the reconstructed 1918 Spanish influenza pandemic virus', Science, vol. 310(5745), pp. 77-80. 
at least) the traits that made the pandemic influenza virus so virulent (the 'Spanish flu' killed around 50 million people). However, the publication of this information gave rise to concerns that would-be bioterrorists could use it to reconstruct this strain of $\mathrm{HlNl}$ for malign purposes. The US National Science Advisory Board for Biosecurity, a non-government advisory body, was asked to consider the relevant papers before publication (in Science and Nature) and concluded that the scientific benefit of the future use of this information on the 1918 virus far outweighed the potential risk of misuse. ${ }^{12}$ We asked the seminar participants: 'Was publication the right thing to do?'

The overwhelming majority favoured publication, and the ensuing discussion typically included appeals to scientific values. As scientific discovery is a cumulative process, as one Canberra participant observed, it is 'essential to provide [publish] methodology so it [the experiment] can be replicated'. Another argument frequently advanced was one that challenged the premise of our second question: 'You can't control publication; we've got the Internet.' In Canberra this elicited the reply 'but you can control publication in a commercial or military context', and one Sydney participant said 'I'm more worried about results not being published because of government classification.' The implication was that governments themselves could secretly be using life-science technology for malign purposes, or that classification could be hindering efforts to protect the community at large. On the latter point, a Brisbane participant argued that 'publication raises awareness and makes us more prepared'. As a way of testing the assumptions underlying the fiercely pro-publication sentiments expressed at all the seminars, we would ask: 'Can you imagine any research results that should not be communicated at all?' At the Melbourne seminar, one participant replied with the hypothetical example of 'accidentally' discovering a method of making HIV transmissible as an aerosol. Under no circumstances, he argued, would he seek to place that method in the public domain.

Our third question (What forms of security oversight, if any, are required for life scientists?) invited participants to critically assess existing and proposed governance mechanisms, whether grounded in specific laws (for example, biosecurity regulations) or ethical principles (for example, professional codes of conduct). Whereas the previous two questions had canvassed possible problems associated with pursuing particular lines of research and communicating results, participants were now offered an opportunity to exchange ideas in a solutions-oriented frame of mind. In this third and final part of the seminar, our aim was to shift life scientists' attention away from the relatively familiar terrain of laboratory techniques and research publication and towards the more exotic realm of national security concerns. As an exercise in awareness-raising,

12 Miller, S. and Selgelid, M.J. (2008) Ethical and philosophical consideration of the dual-use dilemma in the biological sciences, Springer, p. 26. 
we set about acquainting participants with the existence and content of some relevant biosecurity laws as well as a sample code of conduct. It was not our role, however, to champion legal or ethical oversight per se or any specific mode thereof. It was up to those attending the seminar to discuss among themselves whether particular oversight mechanisms were feasible and/or desirable and why.

Turning first to the issue of legal regulation, we framed the security dilemma in the life sciences as follows:

1. Biological weapons threats can emanate from trusted laboratory personnel, even those with high-level security clearances.

2. Governments need to manage the risk of imposing too great a regulatory burden. A reduction in potentially life-saving research, precipitated by scientists opting out of laboratory work, could undermine capacity to resist both natural infectious-disease outbreaks and biological attacks.

We illustrated this dilemma by briefly referring to two recent episodes from the US with which a minority of participants appeared to be familiar. The first example concerned a Yersinia pestis (plague) bacteria expert, Thomas Butler. Formerly chief of the infectious-diseases division at Texas Tech University, Butler was the first US scientist to be put on trial for biosecurity offences under post-9/11 legislation. In the US, federal laws regulate the storage, handling, transfer and disposal of 82 named Biological Select Agents and Toxins (BSATs). Butler faced charges including that he smuggled (that is, transferred without permission) $Y$ pestis, an agent on the BSATs list. In December 2003 a Texas jury found Butler guilty on three charges related to the shipment of samples to a Tanzanian researcher without the proper permit, the package having been labelled merely as 'laboratory materials'.$^{13}$ On 10 March 2004 he was sentenced to two years in prison. The judge had cut seven years off a possible standard nine-year sentence set by federal guidelines, citing testimony that the bacteria shipment was done for humanitarian reasons and that the US Department of Commerce would have approved a transportation permit had Butler applied for one. The judge also cited Butler's early work on treatment of diarrhoeal diseases and oral rehydration as having 'led to the salvage of millions of lives throughout the world'.14

The second example concerned a Bacillus anthracis (anthrax) bacteria expert, Bruce Ivins. A microbiologist employed for 28 years at a US Government laboratory, Ivins committed suicide on 29 July 2008 before he could be

13 Chang, K. 2004, 'Scientist in plague case is sentenced to two years', New York Times, 11 March, p. A18; Piller, C. 2003, 'Plague expert cleared of serious charges in bioterror case', Los Angeles Times, 2 December, p. Al6.

14 United States v Butler, 5:03-CR-037-C, US District Court, Northern District of Texas, 10 March 2004, available: <http://www.fas.org/butler/sentence.html > [viewed 7 January 2010]. 
charged in connection with the anthrax envelope attacks of $2001 .{ }^{15}$ Ivins was a published expert on anthrax vaccines, ${ }^{16}$ and in 2003 had received the US Defense Department's highest civilian honour for his work in this area. ${ }^{17}$ Affidavits for search warrants published by the Federal Bureau of Investigation (FBI) in August 2008 included a description of Ivins's job at the US Army Medical Research Institute for Infectious Diseases in Maryland. One of his tasks was to prepare 'large batches' of aerosolised anthrax bacteria. Animals were then subjected to 'aerosol challenges' to test the effectiveness of vaccines. Ivins knew how to use devices such as lyophilisers, incubators and centrifuges which are 'considered essential for the production of the highly purified, powdered anthrax used in the Fall 2001 mailings' ${ }^{18}$ The picture that emerged from published case documents was that Ivins knew how to make and use biological weapons, and the FBI's scientific and documentary evidence indicating that he did so in 2001 was compelling. ${ }^{19}$

By this stage of the seminar it was easy to elicit opinions, some strongly worded, on what were commonly regarded as shocking real-life experiences of lost innocence in the life sciences. One participant at our Brisbane seminar knew many of the details of Thomas Butler's case and expressed outrage at what he perceived to be an injustice. In Sydney, by contrast, several participants expressed views along the lines of 'he was unlucky; these days you just have to be more careful'. There appeared to be less awareness of, or willingness to talk about, Bruce Ivins, although some participants knew enough to be able to voice doubts about the scientific foundations of the case against him. When this issue was raised at two of the seminars, the facilitators did not express a view but instead pointed to the FBI's decision in May 2009 to commission an independent review of its investigation by the US National Academy of Sciences. ${ }^{20}$

After allowing time for some discussion of the above two criminal cases, the facilitators briefly explained the relevant international legal context and then drew the focus of attention back to Australia. At all four seminars, almost all the participants seemed unaware of the 1972 Convention on the Prohibition of the Development, Production and Stockpiling of Bacteriological (Biological) and Toxin Weapons and on Their Destruction (the Biological and Toxin Weapons Convention or BTWC). However, out of concern that delving too deeply

15 Johnson, C. 2008, 'US settles with scientist named in anthrax cases', Washington Post, 28 June, p. A01.

16 Hewetson, J. F., Little, S. F., Ivins, B. E., Johnson, W. M., Pittman, P. R., Brown, J. E., Norris, S. L. and Nielsen, C. J. 2008, An in vivo passive protection assay for the evaluation of immunity in AVA-vaccinated individuals', Vaccine, vol. 26(33), pp. 4262-6.

17 Dance, A. 2008, 'Death renews biosecurity debate', Nature, vol. 454(7205), p. 672.

18 Dellafera, T. F. 2008, Affidavit in support of search warrant, US Department of Justice, available: < http:// www.usdoj.gov/amerithrax/07-524-M-01\%20attachment.pdf> [viewed 13 August 2008].

19 Johnson, C., Leonnig, C. D. and Wilber, D. Q. 2008, 'Scientist set to discuss plea bargain in deadly attacks commits suicide', Washington Post, 2 August, p. A01.

20 Shane, S. 2009, 'F.B.I. to pay for anthrax inquiry review', New York Times, 7 May, p. A25. 
into legal provisions might be a turn-off for a scientific audience, we felt it was enough simply to display the text of Article 1. The Convention's in-built recognition of the dual-use dilemma is highlighted in italics:

Each State Party to this Convention undertakes never in any circumstances to develop, produce, stockpile or otherwise acquire or retain:

(1) Microbial or other biological agents, or toxins whatever their origin or method of production, of types and in quantities that have no justification for prophylactic, protective or other peaceful purposes;

(2) Weapons, equipment or means of delivery designed to use such agents or toxins for hostile purposes or in armed conflict.

We explained that the BTWC applies to the actions of states rather than individuals, but that the wording of the above provision is reproduced in Australian criminal law. The maximum penalty for an individual convicted of developing, producing, stockpiling, acquiring or retaining biological agents and toxins for a non-peaceful purpose is life imprisonment. ${ }^{21}$ Again, most seminar participants appeared to be unaware of this. However, they were generally much more familiar with the list of 22 SSBAs which we displayed next. Supplementing the general prohibition on bad intentions contained in international and domestic law, the National Health Security Act 2007 authorised the Australian government's recent introduction of detailed rules for the dayto-day activities of those with access to and knowledge of hazardous pathogens. The SSBAs scheme, although similar to the US BSATs scheme (of which Thomas Butler fell foul) that dates from the mid-1990s, is virtually unprecedented in Australia. Of particular interest to seminar participants was the requirement that persons authorised to handle the most dangerous (Tier 1) SSBAs must undergo a National Criminal History check by the Australian Federal Police and a Politically Motivated Violence check by the Australian Security Intelligence Organisation. ${ }^{22}$ It was not our role to explain, attack or defend the SSBAs scheme. Rather, we wanted each of our seminars to be an opportunity for Australian life scientists and students to engage in frank discussion of a clear and present mechanism of security-oriented oversight. Opinions varied as to the wisdom and effectiveness of biosecurity regulations in general. At the Sydney seminar, for example, one participant warned that 'gene-technology regulations [dating from 2000] did impede research' but another said that 'sometimes you have to legislate to bring about changes in behaviour'. A laboratory manager in Sydney observed that 'younger scientists are more likely to adhere to biosafety rules' but additional biosecurity rules would bring, according to a Brisbane

21 Crimes (Biological Weapons) Act 1976(Cth), s 8.

22 Department of Health and Ageing 2009, SSBA Standards, 3.3 Authorised persons, available: <http://www. health.gov.au/ssba\#standards> [viewed 11 January 2010]. 
participant, 'compliance overload'. Another opinion voiced in Brisbane was: 'It's like Aboriginal housing; layers of bureaucracy make it impossible to get things done.' Towards the end of the Sydney seminar, one participant set heads nodding around the room when she warned, 'Don't take away from scientists that love of what they do.'

As many participants were aware, the Department of Health and Ageing runs a nationwide series of workshops for the purpose of instructing life scientists and laboratory managers on the requirements for complying with the SSBAs scheme. However, these workshops are not an opportunity to suggest changes to the rules or challenge the scheme as a whole. As disinterested academics, we were determined through our seminars to facilitate such an opportunity, and participants readily gave voice to a wide array of opinions. These ranged from outright opposition to the SSBAs scheme on the grounds that it inhibited research through to concerns that the scheme was entirely necessary but not strict enough. Declining to express personal views for or against specific modes of security oversight, we suggested that interactive seminars such as ours could be a valuable, empowering and bottom-up means of increasing the security consciousness of life scientists and students. Arguably, this complements rather than conflicts with the top-down regulatory scheme imposed by the National Health Security Act 2007.

Further to the issue of security-oriented oversight, the law does not (and perhaps could not) offer guidance for life scientists making decisions about lines of research (Question 1) and communicating research results (Question 2). These are best regarded as ethical rather than legal issues and, as one Canberra seminar participant commented, 'often it is better to think about moral obligations than regulations'. One mechanism of ethics-based oversight, professionally binding but falling short of actual law, is a code of conduct. The final part of the seminar, drawing all its themes together with possible solutions in mind, invited participants to consider sample principles for a code. We used the example of the 2008 document A Code of Conduct on Biosecurity commissioned by the Royal Netherlands Academy of Arts and Sciences at the request of the Dutch Ministry of Education, Science and Culture. Because a code of conduct can only be useful if it reflects scientific practice, scientists as well as representatives of government and business were from the outset involved in developing this document. ${ }^{23}$ Seminar participants were first shown the Code's 'basic principles', drawing the link back to the international ban on biological weapons:

23 Royal Netherlands Academy of Arts and Sciences 2008, A code of conduct on biosecurity: Report by the Biosecurity Working Group, available: <http://www.knaw.nl/publicaties/pdf/20071092.pdf> [viewed 20 January 2010]. 
The aim of this code of conduct is to prevent life-sciences research or its application from directly or indirectly contributing to the development, production or stockpiling of biological weapons, as described in the Biological and Toxin Weapons Convention (BTWC), or to any other misuse of biological agents and toxins.

We then displayed the suggested elements of the Code with respect to 'research and publication policy' and 'accountability and oversight', in each case asking participants to tell us what they liked or disliked:

\section{Research and publication policy}

- Screen for possible dual-use aspects during the application and assessment procedure and during the execution of research projects.

- Weigh the anticipated results against the risks of the research if possible dual-use aspects are identified.

- Reduce the risk that the publication of the results of potential dual-use lifesciences research in scientific publications will unintentionally contribute to misuse of that knowledge.

\section{Accountability and oversight}

- Report any finding or suspicion of misuse of dual-use technology directly to the competent persons or commissions.

- Take whistleblowers seriously and ensure that they do not suffer any adverse effects from their actions.

The ensuing discussion invariably centred on what the application of such general principles would look like in practice. Seminar participants would typically pick out one or more of the above words and ask a question along the lines of 'What does that really mean?' What did it mean, for example, to 'screen' research? How and by whom are 'possible dual-use aspects' to be 'identified'? What about results that are not 'anticipated'? What does it mean to 'unintentionally contribute' to misuse of knowledge? What are good grounds for 'suspicion' of misuse of technology? What is the difference between a 'whistleblower' and a troublemaker? What constitutes taking something 'seriously'? Such questions, drilling down to the fine detail of how scientists' day-to-day working lives might be affected by a code of conduct, generated excellent and sometimes heated discussions among the seminar participants. Our role as facilitators, we reminded them, was not to answer their questions but to get an informed conversation started on possible solutions to the dualuse dilemma in the life sciences. At the end of each seminar, after thanking the 
participants for their contributions and providing our contact details, it was pleasing to hear conversation continuing in the corridors as people headed back to their places of work.

\section{General Reflections}

It was not the purpose of these seminars for the facilitators to advance a moral position on particular lines of research and publication decisions or to advocate any specific form of oversight to manage the dual-use dilemma. Rather, these were opportunities for loosely structured discussions moderated by impartial, non-government experts. Only rarely did a participant ask us directly for an answer to a question we posed, and such a request was always met with a deliberate and conspicuous sidestep. We were candid about not being able to agree among ourselves, and we admitted that the seminars themselves were an occasion to rethink our opinions, but beyond that we insisted on keeping a low profile. Each of us had come to this awareness-raising project with different intellectual backgrounds (virology, bioethics and political science), and it was sometimes difficult to reconcile our individual views on the kind of content to cover and the best process to follow. In preparing for and debriefing after each seminar, we saw the series evolve and improve. As facilitators, we reflected on what we judged to be mistakes in our own and each other's approach and sought to build on those aspects of previous seminars that seemed to work well.

At all times, however, we needed to be flexible and alert enough to facilitate conversation among seminar participants rather than try too hard to shape it. We needed to be careful, for example, not to be seen to be prefacing questions or pre-empting answers. Lest we appear to be pushing an agenda, we tried to ask open questions (for example, 'What is your moral position, if any, on X?') rather than leading ones (for example, 'Do you think $\mathrm{X}$ is immoral?'). Our language had to be as neutral as possible, abstract rather than personal, to maintain focus on the participants' own views (for example, 'One argument against that might be...', 'Another perspective you might come across is...', 'Can anyone think of a possible counterargument?'). In addition to being impartial, we needed to be inclusive. A consistent feature of all four seminars was that the more senior scientists in the room tended to speak first, at greater length, and contributed statements rather than questions. Most of their contributions were well informed and constructive, but we were sensitive also to the importance of ensuring that the more junior scientists and students had an opportunity to voice opinions as future research leaders. The aim overall was to draw people into articulating their reasoning on how they would navigate a dual-use dilemma, and to flush out the assumptions underlying particular points of view. Our facilitative tasks 
were to attend carefully to what was being said at the time, recall similar or countervailing points raised earlier, anticipate what might be raised next, and keep the conversation moving swiftly enough to cover all our themes.

The experience of designing and running the seminars was both challenging and rewarding, and it was unlike any other academic activity the facilitators had engaged in before. It was a privilege to discuss the dual-use dilemma with some of the most talented life scientists in Australia, and we made some useful professional contacts over the course of 2009. In Canberra, Melbourne, Sydney and Brisbane, we were greatly encouraged seeing seminar participants taking the time and effort to talk seriously about a vexing and intriguing issue. We were made to feel very welcome at every institution we visited, and each seminar proved a valuable learning experience for us too. Although limited in scope, our pilot seminar series seemed to confirm what anecdotal evidence had led us to suspect: that in Australia there is very little familiarity overall with policy issues surrounding the dual-use dilemma in the life sciences. The remedy we proposed, as simply and tactfully as we could, was to get people talking. However distasteful the topic of biological weapons might seem, it is nevertheless an increasingly important one for Australian life scientists and their colleagues around the world. We sought to raise awareness of the dualuse dilemma in a manner sensitive to but not beholden to the interests and concerns of life scientists. Scientific opinions are not the only ones that count; potentially all members of a given community have a stake in this issue. On the other hand, life scientists are historically not closely acquainted with the language and institutions of national security. As such, seminars such as ours might serve as a source of empowerment as well as information. By becoming more familiar with political and policymaking processes, life scientists might be able to suggest better ways of managing the security risks inherent in some research while minimising scientific opportunity costs.

In Australia and beyond, with the health and security stakes so high, there needs to be further exploration of education and awareness-raising as a long-term means of preventing the destructive use of science. Accordingly, the National Centre for Biosecurity is drafting a proposal that the Australian Government fund a nationwide Seminar Programme to raise awareness of the dual-use dilemma among Australian life scientists and students. The Programme would consist of 24 seminars (six in 2011, eight in 2012, and 10 in 2013) and three annual training days for seminar facilitators. The seminars would initially resemble those conducted in the 2009 pilot scheme, and updates and improvements would be made over the succeeding three years. Such an initiative would firstly support Australia's national security and public-health objectives. By raising awareness of biological-weapons risks in a manner sensitive to the interests of scientists, the seminars would facilitate conditions in which biological attacks 
are less likely to emanate from the Australian life-sciences community. Secondly, the Programme would support foreign-policy objectives by strengthening the fulfilment of Australia's international obligations under the 1972 BTWC. Specifically, Article IV obliges member states to take 'any necessary measures' to give effect to the Convention's prohibitions. Lastly, the initiative could provide members of the Australian life-sciences community with a respectable forum to articulate their interests and concerns regarding the dual-use dilemma. 